\title{
HUMAN RIGHTS AND BEYOND: SOME CONCEPTUAL DIFFERENCES BETWEEN ISLAMIC AND WESTERN PERSPECTIVES OF HUMAN RIGHTS••
}

\author{
Dr. Abdulmumini A. Oba
}

\begin{abstract}
The world is pluralistic in many ways. It consists of peoples of diverse racial, ethnic, religious, and cultural backgrounds. Several distinct civilizations have emerged from these diverse peoples. The major civilizations in the contemporary world include Western, Asian, African and Islamic civilizations. With these different civilizations come different ideologies, value systems and worldviews. Although Western civilization has become dominant in the world, Islamic civilization is its major rival. Some have argued that given the fundamental differences between Western and Islamic civilizations, a clash of civilizations is inevitable. This has become apparent particularly in the area of human rights. The international human rights law that emerged in the middle of the last century is dominated by Western thought and historical experience. These human rights lay claim to universality whereas there are conceptual and normative differences between Islamic and Western perspectives of human rights.

This paper examines some of the fundamental differences in the concepts and terminologies used in the human rights discourse in Islamic and Western traditions. It also examines the ideological differences affecting their thinking on human rights, and the differences in conceptualizations and methods of enforcing human rights. This paper argues that the values embodied in the Western conception of human rights are not necessarily superior to those of Islam. On the contrary, some are patently inferior. Universal human rights across both civilizations can only emerge in the context of a genuine crosscultural dialogue when the West changes its perceived positional superiority and accepts Islamic civilization as an equal partner in the quest for the protection of the dignity and welfare of humankind.
\end{abstract}

Key Words: Human Rights, Civilization, Difference, Worldview, West

\footnotetext{
- An earlier version of this paper was prepared for the 'Conference on Islamic Civilization - Potentials and Challenges', organised by the School of Social Sciences and Humanities, Department of Islamic Thought and Civilization, University of Management and Technology, Lahore, Pakistan, March 9-10, 2011.
} 


\section{INTRODUCTION}

The pluralistic world that we inhabit today consists of peoples of diverse racial, ethnic, religious and cultural backgrounds. Several distinct civilizations have emerged from these diverse peoples. Western, Asian, African and Islamic civilizations are the major civilizations in the contemporary world. With these different civilizations come different ideologies, value systems and worldviews which have resulted in different perspectives on human rights. ${ }^{1}$

Islamic civilization is based on Islam - the religion revealed to mankind through the Prophet Muhammad $(S A W)$. Islamic law is the legal expression of the Islamic religion. Although Western critics discussing Islam and human rights point out that Islam is not monolithic (and this is correct to some extent), there are core values that unite all those who profess Islam. References to Islam in this work focus on these core values.

The term "West" is a fluid term with many different meanings. The term is used in this paper to describe a concept or ideology rather than as a geographical expression. It means the civilization that started in Europe from where it spread to other countries across the world. While the Western civilization is not monolithic, in that there are variations in different countries, there are core human right values shared across Western civilization.

Western civilization has become the dominant civilization in the world with Islamic civilization as its major rival. Some have argued that given the fundamental differences between Western and Islamic civilizations, a clash of civilizations is inevitable. $^{2}$ The potential for this clash of civilizations has become apparent, particularly in the area of human rights where Islam has its own distinct human rights concept and norms. ${ }^{3}$

The international human rights law that emerged in the middle of the last century is dominated by Western thought and socio-historical experience. Yet, proponents of these human rights lay claim to universality whereas there are conceptual and normative differences between Islamic and Western perspectives on human rights. The proponents of Western perspective on human rights react to these differences by simply asserting that the concept of human rights is a Western creation unknown

\footnotetext{
${ }^{1}$ For example see discussions of the African perspectives of human rights in Claude Ake, "The African Context of Human Rights" African Today Vol. 34 Nos. 1\& 2, 1987, 5-12, I. G. Shivji, The Concept of Human Rights in Africa (London: CODESRIA, 1989), Makau Wa Mutua, "The Banjul Charter and African Cultural Fingerprint: An Evaluation of the Language of Duties" 6 Revue Afrcaine des Droits de l'Homme (1996-7) 16-48 and A. A. Oba, "The Contributions of the African Charter to Modern Human Rights Thought", The Jurist Vol. 4, 123-131; and Asian Perspectives in Bilahari Kausikan, "Asia's Different Standard" Foreign Policy 1993, Vol. 92, 24-41 and Yash Ghai, "Human Rights and Governance: The Asian Debate" Australia Year Book of International Law, Vol. 15, 1994, 1-34, R. P. Peerenboom, "What's Wrong with Chinese Rights?: Toward a Theory of Rights with Chinese Characteristics" Harvard Human Rights Journal, Vol. 6, 1993, 29-57 and Stephen C. Angle, "Human Rights and Harmony" Human Rights Quarterly Vol. 30, 2008, 76-94.

${ }^{2}$ Samuel Huntington, "The Clash of Civilization?" Foreign Affairs, Vol. 72, 2993.

${ }^{3}$ The scholarship on Islamic perspective of human rights is quite extensive, see Maulana Abu al 'Ala Mawdudi, "Human Rights in Islam" Al-Tawhid, A Quarterly Journal of Islamic Thought and Culture, Vol. IV No. 3 Rajab - Ramadan, 1407 (April - June 1987) 59-89.
} 
to other civilizations. ${ }^{4}$ To them, 'human rights' in other civilizations are not the concepts of human dignity. ${ }^{5}$ This approach makes the West the sole determinant of what norms constitute human rights.

This paper examines some of the fundamental differences in the concepts and terminologies used in the human rights discourse in Islamic and Western traditions. It also examines the ideological differences affecting their thinking on human rights, and the differences in conceptualizations and methods of enforcing human rights. The paper also makes suggestions for reconciling the differences between Islamic and Western human rights.

\section{DIFFERENCES IN CONCEPTS AND TERMINOLOGIES OF HUMAN RIGHTS}

Words and concepts often have culture-specific meanings and connotations. This applies to human rights in Islamic and Western civilizations where there are wide divergences in some of the basic terminologies used in the human rights discourse in the West and the technical meanings of their literary equivalents in Islamic law. The very term "human rights" which contemporary scholars have translated as "huquq al-Insan" is of recent origin in Islamic law. ${ }^{6}$ The term has no legal connotation or significance in classical Islamic law.

Islamic law has the normative equivalents of the scope covered by modern human rights but these norms do not always have the same significance or meaning associated with them as in the concept of modern human rights. ${ }^{7}$ In addition, words such as "rights" (huquq singular, haqq) and "fundamental liberties" (hurriyyah) have legal meanings that are not coterminous with the meanings attached to these words in Western human rights. ${ }^{8}$ Thus, if the Islamic concept of human rights is discussed using Western terminologies, there will be plenty of confusion, distortions and inaccuracies. ${ }^{9}$ Uncritical acceptance of Western terminologies in the Islamic and human rights discourse will render Islamic concepts vulnerable to Westernization. ${ }^{10}$

In discussing the differences between Islamic and Western perspectives of "human rights", one must use the terms whose limitations are described above. It should be understood therefore, that the use of those terms in relation to Islamic law in this paper is in a fluid rather than exact sense.

\footnotetext{
${ }^{4}$ See Jack Donnelly, Universal Human Rights in Theory and Practice (Ithaca and London: Cornell University Press, $2^{\text {nd }}$. Ed., 2003) 71-88.

5 Ibid.

${ }^{6}$ See Maulana Mawdudi, "Human Rights in Islam".

7 Ibid.

${ }^{8}$ See Mohammad Tahir Haji Mohammad, Rights and Duties in Shari'ah and Common Law (Kuala Lumpur: Ilmiah Publishers, 2003) 64-82 and 186-200.

${ }^{9}$ See generally Syed Muhammad Naquib al-Attas, The Concept of Education in Islam (Kuala Lumpur: International Institute of Islamic Thought and Civilization (ISTAC), 1999), 2-12.

${ }^{10}$ Ibid and Mohammad, Rights and Duties in Shari'ah and Common Law, 334.
} 


\section{IDEOLOGICAL DIFFERENCES}

There are fundamental differences in the ideological context of Islam and the West. These differences relate to worldviews, which in turn affect the foundations of human rights, and the relationship between religion and human rights.

\section{Differences in Worldviews}

From the Islamic perspective, humankind and the entire universe have been created by Allah (SWT) to Whom obedience from all creation is due. ${ }^{11}$ When Allah (SWT) created the first human beings (Adam and Eve - peace be upon them), He placed them in paradise but they were deceived by Satan and for this sin, Allah exiled them to earth as a place of test. ${ }^{12}$ Thus, our existence on earth is meant to try us as to whether we will be obedient to Allah or not. We cannot know the Truth unless guided by Allah. ${ }^{13}$ To guide us, Allah (SWT) sent prophets as Messengers who conveyed His Message of Guidance to humankind. ${ }^{14}$ Anyone who follows the Guidance will be admitted to paradise in the hereafter and anyone who disobeys Allah (by following his or her own vain desires) goes into the hellfire. ${ }^{15}$ Thus, human beings are not free beings who can do as they like; they must submit and obey their Lord. ${ }^{16}$

The Western worldview affirms evolution and denies creation. ${ }^{17}$ The West perceives the world and the existence of humankind as the result of a series of accidents. Man evolved from microorganisms into a full-fledged human being and life has no meaning beyond this; we live and we die and there is nothing thereafter. ${ }^{18}$ The Western view takes a secular view that makes human beings the measure of all things and master of their own destiny. While Islam says that truths are ascertainable by revelation and reason, the West says truths are ascertainable by reason alone. ${ }^{19}$

\footnotetext{
${ }^{11}$ Abu Bakr Jabir Al-Jazai'ri, Minhaj al-Muslim (Riyadh: Darussalam, 2001) Vol. I, 25-36.

${ }^{12}$ Imam Imaduddin Ismail Ibn Kathir Ad-Dimashqi, Stories of the Prophets [Peace be on them] (Riyadh: Darussalam, revised edition, 2003) 16-20.

13 "He [Allah SWT] said: 'Get down from here all of you, you are an enemy to each other. Whenever there shall come to you Guidance from Me, then whoever followed My Guidance, shall not go astray nor shall he suffer hardship.' But whoever turned away from my Guidance, then shall he have a straitened life, and We will gather him on the Day of Resurrection blind", Qur'an Taha 20:123-124. See also "The Truth (comes) from Allah alone: so be not of those who doubt", Qur'an Al Imran 3: 60.

${ }^{14}$ See Al-Jazai'ri, Minhaj al-Muslim, Vol. I, 48-75.

${ }^{15} \mathrm{Ibid}, 76-91$.

${ }^{16}$ On the Islamic worldview, see generally ibid., 19-141, Syed Muhammad Naquib Al-Attas, "The Worldview of Islam: An Outline" in Sharifah Shifa Al-Attas, Islam and the Challenge of Modernity: Historical and Contemporary Contexts (Kuala Lumpur: International Institute of Islamic Thought and Civilization, 1996) 25-71 and Abdelaziz Berghout (ed.), Introduction to the Islamic Worldview: Study of Selected Essentials (Kuala Lumpur: IIUM Press, 2009).

${ }^{17}$ See Robert Boyd and Joan B. Silk, How Humans Evolved (New York and London: W. W. Norton, $3^{\text {rd }}$, 2003).

${ }^{18}$ The Qur'an says “And they [disbelievers] say: 'There is nothing but our life of this world, we die and we live and nothing destroys us except ad-Dahr (time)", Qur'an al-Jathiyah 45: 24.

${ }^{19}$ See generally, Louay Safi, The Foundation of Knowledge: A Comparative Study in Islamic and Western Methods of Inquiry (Kuala Lumpur: International Islamic University Malaysia Press and International Institute of Islamic Thought, Malaysia, 1996).
} 
The differences between these worldviews translate into differences in the value systems of both civilizations. To the Muslim, the Quran and the Prophetic traditions constitute an ethical code that he must obey, and a legal system that he must follow without fail. $^{20}$ The Western system relies on man-made laws and completely disregards divine sources. This creates a big divide between Islam and the West and accounts for many of the normative differences in their constructions of human rights and the difficulties in reaching a compromise on these differences.

\section{Differences in the Foundations of Human Rights}

What is the origin of human rights? This question is answered differently by Islam and the West. As pointed out above, Islam says that human rights come from Allah $(S W T)$ while the West looks to reason as the source of human rights. The Western position evolved over time. In the classical era, the West relied on divine sources. ${ }^{21}$ Western philosophers of the natural law school make a distinction between divine law and man-made laws, and they gave precedence to divine law. ${ }^{22}$ However, they ran into problems when it came to the actual legal norms because Christians (having rejected the legal norms contained in the Old Testament) have no other code of law. ${ }^{23}$ Thus, in the absence of divine law to regulate worldly matters, they turned to natural law, the norms of which are ascertainable by reason. ${ }^{24}$ However, while reason may be a methodology of deriving law, it does not provide any foundation or external validity for the norms so derived. ${ }^{25}$ The result is that while human rights in Islam are firmly rooted in divine sources that provide validity for these laws (for Muslims), the West is engaged in an endless quest for the foundations of its human rights.

\section{Differences in the Sources of Human Rights}

Western civilization relies on human reason freely exercised primarily by legislators and often by judges as the means of ascertaining human rights norms. The methods of ascertaining human rights under Islam are based on the formalized system within the ambit of the usul al-fiqh (foundations of legal reasoning). ${ }^{26}$ Islamic values are defined within the parameters of the objectives of Shari'ah (Maqasid al-Shariah)

\footnotetext{
20 "To each among you [Jews, Christians, and Muslims], We have prescribed a law [Shariah] and a clear way [Minhaj]", Qur'an al-Mai'dah 5: 48.

${ }^{21}$ See Michael Freeman, "The Problem of Secularism in Human Rights Theory," Human Rights Quarterly Vol. 26, 2004, 375-400.

${ }_{22}^{2}$ See Dennis Lloyd, The Idea of Law (Harmondsworth: Penguin Books, 1981), 78-81.

${ }^{23}$ On the relevance of Mosaic Law to Christians, see David A. Dorsey, "The Law of Moses and the Christian: A Compromise," Jets Vol. 34 No. 3, 1991, 321-334.

${ }^{24}$ On the exposition of this position by Thomas Aquinas, see Lloyd, The Idea of Law, 80-82 and J. M. Elegido, Jurisprudence (Ibadan: Spectrum Books, reprinted 2006) 33-38.

${ }^{25}$ On the challenges of foundations of human rights in the West, see Donnelly, Universal Human Rights, $18-21$.

${ }^{26}$ See generally Abd al-Wahhab Khallaf, Ilm Usul al-Fiqh (Cairo: Dar al-Hadith, 2003) and Mohammad Hashim Kamali, Principles of Islamic Jurisprudence (Kuala Lumpur: Ilmiah Publishers, $2^{\text {nd }}$ revised ed., 2009).
} 
whose scope and principles have been clearly enunciated by Islamic jurists. ${ }^{27}$ These objectives are concerned with providing benefit (masalih) to the people by prescribing what benefits them and proscribing what brings harm (mafasid) to them. ${ }^{28}$ These principles also provide means of testing from the Islamic perspective, the validity of Western human rights norms. ${ }^{29}$

\section{Differences in the Relationship Between Religion and Human Rights}

Religion and human rights are in harmony in Islam because Islam is the source of human rights. The position in the West is complicated. For centuries, the West purported to be Christian but became Judeo-Christian after the Second World War and finally evolved into a secular post-Christian society. ${ }^{30}$ Secularism, which is now the dominant theory in the West, is hostile to religion. This secularism, which grew within a closed Western society, did not contemplate Islam at all and therefore, it has been very difficult for the West to deal with Islam within the secularist paradigm. Two problems arise in this context.

First, there is the question of definition of religion. In the West, the very definition of religion is controversial. The West tends to define religion as a system of beliefs, which have little to do with practical life except perhaps a few moral injunctions and formal worship on Sundays and other festive days. ${ }^{31}$ This conception of religion is that which pertains to the freedom of religion as embodied in human rights documents in the West. ${ }^{32}$ Thus, even though the West purports to respect freedom of religion, it has problems respecting Islamic norms and values in some matters of family law (especially in matters that the West perceives as violating gender equality such as polygamy and Islamic moral dress code for women ${ }^{33}$ ) and in other matters that the West sees as disruptive to its own commercial or cultural life such as the observance of the five daily prayers, ${ }^{34}$ mosque architecture ${ }^{35}$, and other aspects of practical life. ${ }^{36}$

\footnotetext{
${ }^{27}$ Mohamad Akram Laldin, Introduction to Shariah and Islamic Jurisprudence (Kuala Lumpur: Cert Publications, $2^{\text {nd }}$ ed., 2008) 14-34.

${ }^{33}$ See Abdulmumini Oba. "The Hijab in Educational Institutions and Human Rights: Perspectives from Nigeria and Beyond," Identity, Culture \& Politics: An Afro-Asian Dialogue Vol. 10 No. 1, 2009, 51-74.

${ }^{34}$ A. A. Oba, "The Right to Time for Worship: International Conventions and the Practice in England, America and Nigeria," Journal of Malaysian and Comparative Law Vol. 28, 2001, 69-86.
} 
Secondly, there is the issue of relationship between religion and human rights. The Western approach is that religion must be subservient to human rights. Any religious norms that are contrary to the Western conception of human rights are not tolerated. The West elevates human rights above religion. Christianity in any case is perceived now as no more than fairy tales. ${ }^{37}$ This attitude was extended to all other religions and the West entered a post-Christian and neo-pagan era. ${ }^{38}$ In his brilliant paper, Bahmanpour showed that human rights now fulfill all the roles meant for religion. ${ }^{39}$ Thus, from the Islamic perspective, human rights as currently formulated in the West may be a form of kufr (disbelief) because human rights ignore the divine source ; though some of its norms are consistent with Islamic norms and values, some are also inconsistent with Islamic norms and ethics. It is often difficult for a Muslim who is not a scholar (alim) to discern between what is haram (forbidden) and what is halal (permitted) from the Islamic perspective in the Western human rights norms because these two terms, halal and haram, in Western human rights are often so intertwined that it is difficult to ascertain the demarcation between them.

\section{DIFFERENCES IN CONCEPTUALIZATION OF HUMAN RIGHTS}

\section{The Concept of Fundamental Rights}

Classical Islamic jurists did not make the classification of some rights as human rights or fundamental rights because such a classification is superfluous and irrelevant given Islam's holistic approach to human conduct. Firstly, all actions of man fall into one of the following categories: al-Wajib (obligatory act), al-Mandub (recommended act), al-Haram (prohibited act), al-Makruh (distasteful act) and alMubah (a legally indifferent act). ${ }^{40}$ Rights and duties exist only within these five parameters. Secondly, Islam attaches importance to the fulfillment of all rights and duties, and the categorization of rights is not an important issue. Thus, it is the priority of rights rather than the categorization of rights and duties that matters. The categorization of violations of rights and non-discharge of duties which Islam makes is between those that amount to great sins (al-kaba'ir) and those that are

\footnotetext{
${ }^{35}$ For example, the constitutional amendment banning the construction of minarets in Switzerland following a referendum in November 2009, see "Swiss voters back ban on minarets" at <news.bbc.co.uk/2/hi/8385069.stm> accessed on 23 October 2012.

${ }^{36}$ See an overview of the position in America the post-9/11 era in Mohamed Nimer, The Status of Muslim Civil Rights in the United States 2001: Accommodating Diversity (Washington, D.C.: Council on American-Islamic Relations CAIR Research Center, 2001).

${ }^{37}$ According to Wooton, "To generations reared in a scientific age those [Christian] sanctions no longer have validity, unless for a tiny minority of convinced believers: to the rest the Christian story is a fairy story", Barbara Wooton, Crime and the Criminal Law (London: Stevens and Sons, 1981) 23.

${ }^{38}$ Solzhenitsyn, the Nobel laureate asserted that Western civilization which started as "WesternChristian" has now become "Western-Pagan": Paul Gray, "Russian Prophet in Exile" Interview in TIME, July 22, 1989, 58

${ }^{39}$ Saeed Bahmanpour, "The Religion of Human Rights and Other Religions, Are they Compatible?" (Address to the Conference on Concept of Human Rights from Islamic and Western Perspectives, London, 12 September 2003).

${ }^{40}$ See generally Khallaf, Ilm Usul al-Fiqh, 122-135.
} 
lesser sins. Even this categorization is of little significance in practical terms because of the wide scope of al-kaba' ${ }^{4}{ }^{41}$

\section{Scope and Classification of Fundamental Rights}

The notion of fundamental rights or 'human rights' under Islam is much broader than Western human rights contemplate. Muslim scholars say that in Islam, the rights analogous to the Western human rights concept fall into two distinct categories. These are the rights of Allah the Creator over His creation including man (these rights include the right to acknowledgment as the Creator and the right to be worshipped by man) and the rights that all creatures of Allah have over all other creatures of Allah. ${ }^{42}$ Human rights (which in the Islamic perspective include the right one has over oneself - such as right to adequate rest ${ }^{43}$ ) are subsumed in the latter category.

\section{The Rights of Individuals and the Rights of the Community}

Under Western human rights, human rights are possessed only by human beings individually against the state and the community. ${ }^{44}$ In Islamic law, "fundamental rights" are not only for individuals but also for the community. Islam carefully balances the interests of individuals with public interests (public good and the welfare of the community in general ${ }^{45}$ ) with more premium placed on public interests. ${ }^{46}$ Although the African Charter on Human and Peoples' Rights ${ }^{47}$ and other treaties refer to group rights, collective rights are not widely accepted as human rights in the West. ${ }^{48}$

\footnotetext{
${ }^{41}$ On the scope of $k a b a^{-3} i r$, see generally Imam al-Hafiz Shamusudeen al-Jazairy, Al-kaba'ir (Beirut: Dar al-Fikr, undated).

${ }^{42}$ See generally, 'Abdul Rahman Shad, The Rights of Allah and Human Rights (Lahore: Kazi Publications, 1981). These rights include the rights of animals; see Al-Jazai’ri, Minhaj al-Muslim, 228232.

${ }^{43}$ Salman (May Allah be pleased with him) advised Abu Darda' (May Allah be pleased with him) who had abstained from the world and spent his days fasting, nights in prayer and keeps away from sexual intercourse with his wife thus: "It is true you owe your duty to your Lord, but you also owe a duty to yourself and you owe a duty to your wife. So you should render to everyone their due". When they reported this to the Prophet (SAW), the Prophet said, "Salman was right". Imam Nawawi, Gardens of the Righteous (Riyadh as-Salihin of Imam Nawawi, translated from Arabic by Muhammad Zafrulla Khan) (London: Curzon Press, 1974) 37 (Hadith No. 149). In another hadith, the Prophets (SAW) admonished three persons who vowed to spend all his nights in prayer, to observe fasting every day, and to abstain from marriage (so as to devote himself to worship) respectively: "Now, I fear Allah more than you do and am more mindful of my duty to Him than you are, but I observe a fast and also abstain from fasting, and I perform voluntary Prayer at night and also sleep, and I consort with my wives. He who turns away from my practice is not of me", ibid, 36 (Hadith No. 143).

${ }^{44}$ Donnelly, Universal Human Rights, 10 and 112-114.

${ }^{45}$ Mohammad Tahir Haji Mohammad, Rights and Duties in Shari'ah and Common Law (Kuala Lumpur: Ilmiah Publishers, 2003) 287.

${ }^{46}$ I. A. Nyazee, Islamic Jurisprudence (Islamabad: International Institute of Islamic Thought, 2000) 211212.

${ }^{47}$ OAU Doc. CAB/Leg/67/3/Rev. 5. See text in (1981) 21 International Legal Materials 58 and Schedule to the African Charter on Human and Peoples' Rights (Enforcement and Ratification) Act, Cap. 10, Laws of the Federation of Nigeria, 1990.

${ }^{48}$ See Jack Donnelly, Human Rights, Individual Rights and Collective Rights” in Jan Berting, Peter Beaher, J. Herman Burgers, Cees Flintman, Babara de Klerk, Rob Kroes, C. van Minnen and Koo
} 


\section{RIGHTS AND DUTIES}

In Islam, rights and duties are closely related. ${ }^{49}$ While some modern human rights documents, such as the African Charter, provide for rights and duties, Western scholars generally consider the idea of duties as part of human rights a contradiction in terms. ${ }^{50}$

\section{a. Unity of Rights and Duties}

There is a great difference in the manner of couching rights under Islamic human rights and Western human rights. The Western approach is the declaratory approach whereby rights are declared without reference to those who have the duty to observe or protect these rights, or the rights are to be enforceable before an official organ or tribunal. The Islamic approach protects human rights by couching rights in the form of duties incumbent on someone.

\section{b. Contextualization of Rights and Duties}

Rights and duties are contextual or status-based under Islam. Islam puts rights and duties within the context of human relationships and thus tackles the problem of "otherness" effectively. Thus, there are rights and duties within relationships such as blood relations, co-religionists, marital relationships, neighbours, employer/employee, and citizen/State. In this way, 'rights' are precisely stated and thus less susceptible to capricious judicial interpretations.

The contextualization of rights applies also to communities and nations. In political terms, Islam divides the world of man into three zones, namely, the abode of Islam (Dar al-Islam) that is "the Islamic State", the land of disbelievers (Dar al-Harb) where Islam is not tolerated, and the land where Islam is tolerated because there is a treaty between Muslims and its inhabitants (Dar al-sulh) ${ }^{51}$ Islam recognizes that the rights accorded to Muslims in each of these places necessarily vary.

The Islamic approach to human rights that is based on status and context, contrasts with the Western approach which is based on general and nebulous statements whose ambits are never predictable. Examples of such statements are the twin principles of equality of persons and non-discrimination. Hence, Bentham in the $19^{\text {th }}$ century dismissed human rights as "nonsense on stilts" 52 and Lord Denning echoed the same sentiment in the $20^{\text {th }}$ century when he declared that human rights

VanderWal (eds.), Human Rights in a Pluralist World: Individual and Collectivities (Westport and London: Meckler, 1990) 39-62. See also the review in Douglas Sanders, "Collective Rights," Human Rights Quarterly, Vol. 13 No. 3, 1991, 368.

${ }^{49}$ See Mohammad, Rights and Duties, 305-320.

${ }^{50}$ Ann Elizabeth Mayer, Islam and Human Rights (Boulder, Colorado: Westview Press, $3^{\text {rd }}$ ed., 1999) 6061 and Donnelly, Universal Human Rights, 18-10 and 72.

${ }^{51}$ Said Ramadan, Islamic Law: Its Scope and Equity (London: second edition, 1970) 157.

522 Jeremy Bentham, "Anarchical Fallacies" in John Bowring (ed.), The Works of Jeremy Bentham (Edinburgh: William Tait, 1843) 489, 501 (cited in John Witte, Jr and Don S. Browning, "Christianity's Mixed Contributions to Children's Rights: Traditional Teachings, Modern Doubts," Emory Law Journal Vol. 61, 2012, 991-1114 at 1000). See also a review of Bentham's views on human rights in Hugo Adam Bedau, “'Anarchical Fallacies: Bentham's Attack on Human Rights' " Human Rights Quarterly Vol. 22, No. $1,2000,261-279$. 
are no more than "high-sounding principles, they have to be brought down to earth". 53

However, there is also contextualization of human rights according to status in the Western system but these are rarely understood as such and thus do not form part of the Western discourse on human rights. Examples include the discriminations and differentiations of rights between classes of citizens such as citizens by birth, naturalization registration, non-citizens, and immigrants. These are not seen as discriminations or violations of rights.

Another form of contextualization of human rights in the West is the dichotomy between human rights and civil rights and liberties recognized at international level in the "margin of appreciation" concept in the European Union. ${ }^{54}$

\section{c. Fixed Rights and Duties}

Islam protects human rights from the vagaries of human beings by making them secure from the arbitrariness of those in the political, judicial or intellectual leaders of their communities since Islam defines these rights in fixed and simple contextual terms. Western human rights have been nebulous; changing and new "human rights norms" can emerge any time.

\section{d. Differences in the Unity of Human Rights and Human Dignity}

Some Western human rights scholars make a distinction between human rights and other methods of attaining human dignity. ${ }^{55}$ To Donnelly, the "conceptions of justice, political legitimacy, and human flourishing that sought to realize human dignity... are alternatives to, rather than different formulations of, human rights". 56 He also believes that "[n]othing is gained by confusing human rights with justice, fairness, limited government, or any other values or practices". 57 Islam's holistic approach to life would not accept the concept of human rights that ignores justice and human dignity. ${ }^{58}$

\footnotetext{
${ }^{53}$ [1978] 1 Q.B 36 at 42. See also Lord Denning, What Next in the Law (London: Butterworths, 1982) 284.

${ }^{54}$ See generally Eyal Benvenisti, "Margin of Appreciation, Consensus, and Universal Standards," International Law and Politics Vol. 31, 1999, 843 and C. S. Feingold, "The Doctrine of Margin of Appreciation and the European Convention on Human Rights," Notre Dame Law Review, Vol. 53 1977, 90.

${ }^{55}$ See generally Donnelly, Universal Human Rights, 71-88.

${ }^{56}$ Ibid, 71

${ }^{57}$ Ibid, 87.

${ }^{58}$ On the fundamental importance of human dignity and justice in Islamic thought, see 'Umar Ahmad Kasule, Pursuit of Human Dignity and Justice: Islamic Alternative Values to Human Rights (Kuala Lumpur: A. S. Noordeen, 2008).
} 


\section{Differences in Methods of Enforcing Human Rights}

Litigation in the courts is the main method of enforcing human rights in the West. Since violators of human rights are usually powerful persons, organizations and governments, this places the victim at a disadvantage. Litigation (under the common law) gives the mighty power to wear out the weak because the processes are generally too technical, expensive and time consuming. ${ }^{59}$ Islam tries to ensure the protection and enforcement of human rights through the duties approach. Islam also provides for enforcement of rights in the judicial forum by the Qadi who examines all the witnesses and provides free non-partisan legal assistance to all the parties in the litigation. ${ }^{60}$

Islam enforces human rights through administrative authorities and in particular by the Mazalim, a precursor of the modern ombudsman, who has the responsibility to look into and remedy oppression by public officials. ${ }^{61}$ Islam remedies this and other weaknesses in the secular system by providing for spiritual sanctions, which may occur in this world or in the hereafter. Under the Western model, a violator of rights who for whatever reason is not taken to account by the worldly authorities has escaped his just desserts whereas Islam promises retribution on the Day of Judgment.

\section{RECONCILING THE DIFFERENCES BETWEEN ISLAMIC AND WESTERN HUMAN RIGHTS}

The differences highlighted above point to a possible clash of civilization between the West and Islam. ${ }^{62}$ However, many have rightly argued that such a clash is not inevitable as it can be easily averted. ${ }^{63}$ The differences between the Islamic and Western perspectives of human rights though vast, are reconcilable. First, we should find out the norms of human rights and dignity upon which there is a consensus across virtually all civilizations. ${ }^{64}$ These should form the core universal human rights. ${ }^{65}$ Secondly, the distinction between human rights, civil rights and liberties

\footnotetext{
${ }^{59}$ Catherine Elliot and Frances Quinn, English Legal System $8^{\text {th }}$ edition, (Essex: Pearson Longman, 2007) 478-479.

${ }^{60}$ See Salim Farrar, "The Role of the Defence in Islamic Law," Sydney Law School Legal Studies Research Paper No. 10/42, May 2010 available at the Social Science Research Network Electronic Library at <http://ssrn.com/abstract=1600503> accessed on 7 September 2010. On the Islamic judicial process, see an overview in M. K. Masud, Ruud Peters, and David S. Powers, "Qadis and Their Courts" in M. K. Masud, Ruud Peters, and David S. Powers, (eds.), Dispensing Justice in Islam: Qadis and Their Judgments (Leiden and Boston: Brill, 2006) 1-44.

${ }^{61}$ Al-Māwardì, The Ordinances of Government: A Translation of Al-Ahkam al-Sultaniyya wa al-Wilayah Al-Diniyya (translated by Wafaa H. Wahba) (London: Garnet Publishing Ltd., 1996) 90-95 and AbdulQadir Zubair, "Human Rights in Islam: Theory and Implementation" Al-Hadli (Justice) 2006: 45 at 5255.

${ }^{62}$ See generally Samuel Huntington, The Clash of Civilization and the Remaking of World Order (New York: Simon \& Schuster, 1996).

${ }^{63}$ Alhagi Manta Drammeh, The Fallacy of the Inevitability of Clash of Civilizations: A Common Ground for Mutual Understanding and Co-Existence (Kuala Lumpur: IIUM Press, 2009).

${ }^{64}$ Alison Dundes Renteln, "Relativism and the Search for Human Rights," American Anthropologist Vol. 90, 1988, 56-72.

${ }^{65}$ Ibid.
} 
can be used to strike a balance between Islamic and Western perspectives of human rights. Some rights are both human rights and civil rights but not all civil rights are (or should be) human rights. Civil rights that are peculiar to some civilizations should not qualify as human rights. An example is gay rights. Thus, while gay rights are recognized in Western civilization and countries, other civilizations (and countries) need not accept this 'human right' that is in many ways fundamentally inimical to their values. Thirdly, the diversity of human rights between Islam and the West cannot be easily or appropriately reduced to one of cultural diversity. Rather, it should be seen as one of civilizational diversity. ${ }^{66}$

The conceptual differences between Islamic and Western perspectives of human rights have not received the attention they deserve. Most of the scholarship on Islam and human rights are directed mainly towards the normative aspects of human rights. Criticisms of Islamic human rights may appear valid if considered exclusively within the ethical parameters of the West that gave birth to Western human rights. However, using the parameters of Western civilization is not an appropriate way to compare Islamic and Western civilizations. Such a method assumes not only the correctness and superiority of the Western perspectives but also the wrongness and inferiority of the Islamic perspectives. Solzhenitsyn, the Nobel Laureate, rightly condemned such an attitude when he said:

The mistake of the West...is that everyone measures other civilizations by the degree to which they approximate Western civilization. If they do not approximate it, they are hopeless, dumb, reactionary and don't have to be taken into account. This viewpoint is dangerous. ${ }^{67}$

Western criticisms of the Islamic perspectives of human rights stem from the fundamental civilizational differences between the Islamic and Western civilizations in the matters of rights in general and human rights in particular.

There should be genuine cross-civilizational dialogue between Islam and the West. Until now, the human rights discourse is largely a monologue going on in the West. The dominant views in the West generally insist on Islam and other civilizations complying with international human rights norms without requesting for any shift from the West. The discourse is devoid of the 'give and take' compromise inherent in dialogues. ${ }^{68}$ Even to some contemporary Muslim scholars, "dialogue" consists only of finding ways to adapt Islamic norms to Western human rights. ${ }^{69}$

\footnotetext{
${ }^{66}$ Onuwa Yasuki, "Towards an Intercivilizational Approach to Human Rights," in Joanne R. Bauer and Daniel A. Bell (eds.), The East Asian Challenge for Human Rights (Cambridge: Cambridge University Press, 1999) 103-123.

${ }^{67}$ Solzhenitsyn's response in an interview in Paul Gray, "Russia's Prophet in Exile" TIME, July 22, 1989,54 at 58.

${ }^{68}$ For example see Donnelly, Universal Human Rights in Theory and Practice, and Heiner Bielefeldt, "Muslim Voices in the Human Rights Debate" Human Rights Quarterly Vol. 17, 1995, 597-617.

${ }^{69}$ See for example, Abdullahi Ahmed An-Na'im, "State Responsibility under International Human Rights Law to Change Religious and Customary Laws" in Rebecca J. Cook (ed.), Human Rights of Women: National and International Perspectives (Philadelphia: University of Pennsylvania Press, 1994) $167-188$
} 
The obstacles to inter-civilizational dialogue between Islam and the West are more formidable than the differences in the conceptual and normative human rights differences between the two civilizations. The main difficulty lies in the domineering attitude of the West to other peoples in the world. This domination found intellectual support in various Eurocentric theories that proclaim the superiority of the West. ${ }^{70}$ These theories say that the only path for the progress of other peoples is to follow the Western pattern. This Eurocentric approach, which consisted of denial of civilization in non-Western cultures, cultural evolution and Social Darwinism, now manifests itself in contemporary times in Western cultural imperialism and in barely disguised forms such as Fukuyama's End of History. ${ }^{71}$ Some Muslim scholars are now saying that it is futile trying to reconcile Islamic human rights and Western human rights in the face of the uncompromising attitude of the West. They are now asserting Islamic alternatives to the modern human rights system. $^{72}$ This is the proper option for Muslims.

\section{CONCLUSION}

The paper argues that the norms embodied in the Islamic and Western perspectives of human rights are based on their respective worldviews and value systems. Their differences cannot be reconciled in the sense of declaring one as superior to the other since their differences stem from equally valid choices or different ways of achieving the same objective of protecting human dignity. They both have relative superiority in that their adherents perceive them so. Yet, we must all live together in harmony. This demands understanding and sincerity on both sides.

There is no doubt that the current drive and upsurge of attention human rights receive in the world today is due to the initiatives taken in the West. However, universal human rights across Islamic and Western civilizations can only emerge in the context of a genuine inter-civilizational dialogue. The West must therefore, change its perceived positional superiority and accept Islamic civilization as an equal partner in the quest for the protection of the dignity and welfare of humankind. However, even before this, there is need for internal dialogue within both civilizations. The human rights record of many Muslims and Western countries is generally poor and there is a wide divergence between the human rights theories they purport to adhere to and their actual practice. There is therefore the need for more concerted efforts among both Muslim and Western countries towards realizing human rights as dictated by their respective human rights theories.

\footnotetext{
${ }^{70}$ See an overview of these theories in A. A. Oba, "Eurocentric Theories as Obstacles to Inter-Cultural Human Rights Dialogue Between the West and Africa" (Paper prepared for the Dialogue among Cultures: Peace, Justice and Harmony", ISUD 8th World Congress International Society for Universal Dialogue (ISUD), Beijing International Studies University Beijing, China, 2-7 July 2010) available online at <isud.typepad.com/files/obal.doc > accessed on 12 July 2012.

${ }^{71}$ Ibid and Francis Fukuyama, The End of History and the Last Man (Penguin, 1992).

${ }^{72}$ See for example Kasule, Pursuit of Human Dignity and Justice.
} 


\section{SELECTED BIBLIOGRAPHY}

1. Ake, Claude. "The African Context of Human Rights", African Today 34 Nos. $1 \& 2$, (1987); 5-12.

2. Al-Attas, Syed Muhammad Naquib. "The Worldview of Islam: An Outline" in Sharifah Shifa Al-Attas, Islam and the Challenge of Modernity: Historical and Contemporary Contexts. Kuala Lumpur: International Institute of Islamic Thought and Civilization, 1996.

3. Al-Attas, Syed Muhammad Naquib. The Concept of Education in Islam. Kuala Lumpur: International Institute of Islamic Thought and Civilization (ISTAC), 1999.

4. Al-Jazai'ri, Abu Bakr Jabir. Minhaj al-Muslim. Vol. I. Riyadh: Darussalam, 2001.

5. Al-Mawardi, The Ordinances of Government: A Translation of Al-Ahkam al-Sultaniyya wa al-Wilayah Al-Diniyya translated by Wafaa H. Wahba. London: Garnet Publishing Ltd., 1996.

6. Angle, Stephen C. "Human Rights and Harmony" Human Rights Quarterly 30, (2008): 76-94.

7. An-Na'im, Abdullahi Ahmed. "State Responsibility under International Human Rights Law to Change Religious and Customary Laws" in Rebecca J. Cook (ed.), Human Rights of Women: National and International Perspectives Philadelphia: University of Pennsylvania Press, 1994. 167-188,

8. Baderin, Mashood A. International Human Rights and Islamic Family Law. Oxford: Oxford University Press, 2003.

9. Bahmanpour, Saeed. "The Religion of Human Rights and Other Religions, Are they Compatible?" (Address to the Conference on Concept of Human Rights from Islamic and Western Perspectives, London, 12 September 2003).

10. Bedau, Hugo Adam “Anarchical Fallacies: Bentham's Attack on Human Rights.” Human Rights Quarterly 22, No. 1, (2000): 261-279.

11. Bentham, Jeremy. "Anarchical Fallacies" in John Bowring (ed.), The Works of Jeremy Bentham. Edinburgh: William Tait, 1843.

12. Benvenisti, Eyal. "Margin of Appreciation, Consensus, and Universal Standards," International Law and Politics 31, (1999): 843

13. Berghout, Abdelaziz. (ed.), Introduction to the Islamic Worldview: Study of Selected Essentials. Kuala Lumpur: IIUM Press, 2009.

14. Boyd, Robert. and Joan B. Silk, How Humans Evolved. New York and London: W. W. Norton, $3^{\text {rd }}$, 2003.

15. Denning, Lord. What Next in the Law. London: Butterworths, 1982.

16. Donnelly, Jack. Human Rights, Individual Rights and Collective Rights" in Jan Berting, Peter Beaher, J. Herman Burgers, Cees Flintman, Babara de Klerk, Rob Kroes, C. van Minnen and Koo VanderWal (eds.), Human Rights in a Pluralist World: Individual and Collectivities. Westport and London: Meckler, 1990.

17. Donnelly, Jack. Universal Human Rights in Theory and Practice. Ithaca and London: Cornell University Press, $2^{\text {nd }}$. Ed., 2003.

18. Donnelly, Universal Human Rights in Theory and Practice, and Heiner Bielefeldt, "Muslim Voices in the Human Rights Debate," Human Rights Quarterly Vol. 17, (1995): 597-617.

19. Dorsey, David A. "The Law of Moses and the Christian: A Compromise," Jets 34, No. 3 (1991): 321-334. 
20. Drammeh, Alhagi Manta. The Fallacy of the Inevitability of Clash of Civilizations: A Common Ground for Mutual Understanding and Co-Existence. Kuala Lumpur: IIUM Press, 2009.

21. Dundes, Alison. "Relativism and the Search for Human Rights," American Anthropologist Vol. 90, (1988): 56-72.

22. Elegido, J. M. Jurisprudence. Ibadan: Spectrum Books, reprinted 2006.

23. Elliot, Catherine and Frances Quinn, English Legal System $8^{\text {th }}$ Edition, Essex: Pearson Longman, 2007.

24. Farrar, Salim. "The Role of the Defence in Islamic Law," Sydney Law School Legal Studies Research Paper No. 10/42, May 2010 available at the Social Science Research Network Electronic Library at <http://ssrn.com/abstract=1600503> accessed on 7 September 2010.

25. Feingold, C. S. "The Doctrine of Margin of Appreciation and the European Convention on Human Rights," Notre Dame Law Review, 53 (1977): 90.

26. Freeman, Michael. "The Problem of Secularism in Human Rights Theory," Human Rights Quarterly Vol. 26, (2004): 375-400.

27. Fukuyama, Francis The End of History and the Last Man. Penguin, 1992.

28. Ghai, Yash. "Human Rights and Governance: The Asian Debate" Australia Year Book of International Law, 15, (1994): 1-34.

29. Gray, Paul. "Russian Prophet in Exile" Interview of Solzhenitsyn in TIME, July 22, 1989, 58.

30. Gunn, T. Jeremy. "The Complexity of Religion and the Definition of 'Religion' in International Law," Harvard Human Rights Journal Vol. 16, (2003): 189-215.

31. Huntington, Samuel. "The Clash of Civilization?" Foreign Affairs, 72, (1993).

32. Huntington, Samuel. The Clash of Civilization and the Remaking of World Order. New York: Simon \& Schuster, 1996.

33. Ibn Kathir Ad-Dimashqi, Imam Imaduddin Ismail. Stories of the Prophets [Peace be on them]. Riyadh: Darussalam, revised edition, 2003.

34. Imam al-Hafiz Shamusudeen al-Jazairy, Al-kaba’ir. Beirut: Dar al-Fikr, undated.

35. Kamali, Mohammad Hashim. Principles of Islamic Jurisprudence. Kuala Lumpur: Ilmiah Publishers, $2^{\text {nd }}$ revised ed., 2009.

36. Kasule, 'Umar Ahmad. Pursuit of Human Dignity and Justice: Islamic Alternative Values to Human Rights. Kuala Lumpur: A. S. Noordeen, 2008.

37. Kausikan, Bilahari. “Asia's Different Standard” Foreign Policy 92, (1993): 24-41

38. Khallaf, Abd al-Wahhab. Ilm Usul al-Fiqh. Cairo: Dār al-Hadìth, 2003.

39. Laldin, Mohamad Akram. Introduction to Shariah and Islamic Jurisprudence. Kuala Lumpur: Cert Publications, $2^{\text {nd }}$ ed., 2008.

40. Lloyd, Dennis. The Idea of Law. Harmondsworth: Penguin Books, 1981.

41. Masud, M. K. and Ruud Peters, and David S. Powers, "Qadis and Their Courts" in M. K. Masud, Ruud Peters, and David S. Powers, (eds.), Dispensing Justice in Islam: Qadis and Their Judgments. Leiden and Boston: Brill, 2006.

42. Mawdudi, Abu al 'Ala. "Human Rights in Islam" Al-Tawhid, A Quarterly Journal of Islamic Thought and Culture IV, No. 3 Rajab - Ramadan, 1407 (April - June 1987): 5989.

43. Mayer, Ann Elizabeth. Islam and Human Rights. Boulder, Colorado: Westview Press, $3^{\text {rd }}$ ed., 1999.

44. Mohammad, Mohammad Tahir Haji. Rights and Duties in Shari'ah and Common Law. Kuala Lumpur: Ilmiah Publishers, 2003. 
45. Mohammad, Mohammad Tahir Haji. Rights and Duties in Shari'ah and Common Law. Kuala Lumpur: Ilmiah Publishers, 2003.

46. Mutua, Makau Wa. "The Banjul Charter and African Cultural Fingerprint: An Evaluation of the Language of Duties" 6, Revue Afrcaine des Droits de l'Homme (19967): $16-48$

47. Nawawi, Imam. Gardens of the Righteous (Riyadh as-Salihin of Imam Nawawi, translated from Arabic by Muhammad Zafrulla Khan). London: Curzon Press, 1974.

48. Nimer, Mohamed. The Status of Muslim Civil Rights in the United States 2001: Accommodating Diversity. Washington, D.C.: Council on American-Islamic Relations CAIR Research Center, 2001.

49. Nyazee, I. A. Islamic Jurisprudence. Islamabad: International Institute of Islamic Thought, 2000.

50. Oba, A. A. "Eurocentric Theories as Obstacles to Inter-Cultural Human Rights Dialogue Between the West and Africa" (Paper prepared for the Dialogue among Cultures: Peace, Justice and Harmony", ISUD 8th World Congress International Society for Universal Dialogue (ISUD), Beijing International Studies University Beijing, China, 2-7 July 2010) available online at <isud.typepad.com/files/oba1.doc> accessed on 12 July 2012.

51. Oba, A. A. "The Contributions of the African Charter to Modern Human Rights Thought" The Jurist 4, 123-131.

52. Oba, A.A. "The Right to Time for Worship: International Conventions and the Practice in England, America and Nigeria," Journal of Malaysian and Comparative Law Vol. 28, (2001): 69-86.

53. Oba, Abdulmumini. "The Hijab in Educational Institutions and Human Rights: Perspectives from Nigeria and Beyond," Identity, Culture \& Politics: An Afro-Asian Dialogue 10 No. 1, (2009): 51-74.

54. Peerenboom, R. P. "What's Wrong with Chinese Rights?: Toward a Theory of Rights with Chinese Characteristics", Harvard Human Rights Journal, 6, (1993): 29-57.

55. Ramadan, Said. Islamic Law: Its Scope and Equity. London: second edition, 1970.

56. Safi, Louay. The Foundation of Knowledge: A Comparative Study in Islamic and Western Methods of Inquiry. Kuala Lumpur: International Islamic University Malaysia Press and International Institute of Islamic Thought, Malaysia, 1996.

57. Sanders, Douglas. "Collective Rights," Human Rights Quarterly, 13 No. 3, (1991): 368.

58. Shād, 'Abdul Rahman. The Rights of Allah and Human Rights. Lahore: Kazi Publications, 1981.

59. Shivji, G. The Concept of Human Rights in Africa. London: CODESRIA, 1989.

60. Witte, Jr. John and Don S. Browning, “Christianity's Mixed Contributions to Children's Rights: Traditional Teachings, Modern Doubts," Emory Law Journal 61, (2012): 9911114.

61. Wooton, Barbara. Crime and the Criminal Law. London: Stevens and Sons, 1981.

62. Yasuki, Onuwa. "Towards an Intercivilizational Approach to Human Rights," in Joanne R. Bauer and Daniel A. Bell (eds.), The East Asian Challenge for Human Rights. Cambridge: Cambridge University Press, 1999.

63. Zubair, Abdul-Qadir. "Human Rights in Islam: Theory and Implementation", Al-Hadli (Justice)(2006): 45. 